\title{
THE GLOBALIZATION PROCESS OF THE UKRAINIAN SOCIETY AS A UNIVERSAL FORM OF HISTORICAL DYNAMICS
}

Purpose. The article covers the impact of globalization on the development and formation of the Ukrainian society.

Methods. The study used general scientific and special methods: scientific generalization and systematization - to determine the characteristics of globalization; comparative analysis - to compare the development of the countries that are members of the European Union with other countries whose government is seeking integration with Europe; systematic analysis - to identify the positive and negative aspects of the impact of globalization on the socio-economic and political development of some countries in the world; logical synthesis - to explain the results of the research.

Results. It has been researched that globalization as a whole and world economic relations, in particular, is an objective process that expresses the totality of conditions of development of the modern world community and, first of all, scientific and technical and economic progress. This is an inevitable stage of the ascension of humanity to new horizons, which ultimately has positive beginnings, but at the same time is not devoid of serious and large-scale contradictions, and therefore does not exclude negative influences. It is analyzed that the main negatives of globalization is the dominance of the "wealthier" country over the less developed in the economic and even cultural spheres. The downsides also include the commercialization of the cultural values. Globalization in its present form is subordinated to the interests of the world capital (transnational corporations) operating using the military-political power of the leading Western powers. However, these states themselves are leading the world globalization process in the pursuit of their own geopolitical interests. Conclusions. It is determined that the functioning of the economy of Ukraine does not comply with international legal norms in terms of taxation system, regulatory system, transparency of financial transactions, etc., which is the cause of unfavorable investment climate. Despite the high level of declarations made about the need to attract foreign investment, there is in fact no sound policy strategy for the creation of a favorable investment climate.

Key words: globalization, policy, European integration, national economy, government.

JEL Classification: H100, H 190, A100.

\section{Ivan SHKURAT,}

Associate Professor

of Department of Political Science

of Hryhorii Skovoroda

University in Pereyaslav,

Doctoral Student of the Institute

of Personnel Training

of the State Employment Service

of Ukraine,

Candidate of Science

in Public Administration

ishiva@ukr.net

https//orcid.org/0000-0002-8810-2890

\section{Introduction}

The positive impact of globalization is the significant and steady increase in world industrial production and trade, the almost universal decline in inflation, the widespread introduction of new principles and methods of the economic activity. The current undeniably high rate of the structural change, for certain, cannot be stored indefinitely, as there are actually limits to how far globalization processes can go. Full-fledged globalization - in which trade and finance are regulated only by a risk-adjusted rate of return, and in itself the risk factor does not depend on distances and national borders - is hardly achievable. Globalization in general and world economic relations, in particular, is an objective process that expresses the totality of conditions for the development of the modern world community and, above all, scientific, technical and economic progress. This is an inevitable stage of the ascension of humanity to new horizons, which ultimately has positive beginnings, but at the same time is not devoid of serious and large-scale contradictions, and therefore does not exclude negative influences. Participation in a process that is not clear makes such a participant the object of the process, and real knowledge makes it possible to influence and benefit from the 
course of events. We believe that the essence of the process of globalization is that no phenomenon (economic, social, legal, political, military, etc.), any process in the society, in our life, however large or, by contrast, small was, can not be considered as itself. The interconnectedness and interdependence of individual actions, phenomena and processes is intensifying, requiring the consideration and evaluation of the opposite effect, of all consequences, both close and distant, in the immediate and remote areas.

\section{Literature review}

This topic has been explored by many national and foreign scholars and practitioners, in particular V. Andrushchenko, V. Volynka, V. Liakh, V. Pazenko, M. Mykhalchenko, R. Voitovych (Voitovych, 2012), O. Molnar (Molnar et al., 2006), Y. Pavlenko (Pavlenko, 2000), A. Pekhnyk, Y. Prysyazhnyuk (Pekhnyk, Prysiazhniuk, 2018), V. Sidenko (Sidenko, 2012), S. Sokolenko (Sokolenko, 2002), O. Toffler, R. Robertson, M. Castels, F. Fukuyama, S. Huntington and others. The scientists have thoroughly explored the main problems and prospects of integration policy in Ukraine in the age of globalization.

3. The purpose of the article is to explore the concept of "globalization", its main directions, advantages and disadvantages.

\section{Empirical results}

Ukraine has the potential to become not just a European, but a global state, and if it adopts and develops global values, it will be able to become even higher than Europe. Europe is now living rather than global values, but European values, and globalization is only an element of trade for it. And as soon as Ukraine is able to overcome Europe's limitations on its own, Europe itself will be interested in Ukraine becoming a part of it. Therefore, the question is whether Ukraine will be able to use the world's resources not only to survive, but also to influence others. And its purpose must be to organize itself and to absorb the global values beyond the narrow borders of Europe. Innovative development of a society is possible under the condition of the state policy of promoting the development of entrepreneurship through its various forms, as well as encouragement at the level of enterprises of the development of entrepreneurial earnings in their own employees (Sokolenko, 2002: 35). That is, summing up what the scientist can say that the innovative development of the society is possible on the condition of a timely, ubiquitous and universal initiative.

Globalization is a relatively new and highest stage in the development of the process of internationalization of numerous aspects of the social life (Pavlenko, 2000). Globalization as a universal form of historical dynamics leads to qualitative and quantitative changes in the functioning of the transitional societies (Voitovych, 2012).

According to V. Sidenko it is possible to speak about the high probability that at the first stages of implementation of the concept of integration development within the Common Economic Space (hereinafter - the CES) there will be a discrepancy in certain economic parameters with the standards of the European Union (hereinafter - the EU) (Sidenko, 2012). For example, there is a problem of widespread harmonization of Ukraine's economic mechanisms with the CES member-states. At the same time, we have similar commitments to the European Union. So in alignment with which economies do we focus? Perhaps it should be made clear that we will coordinate economic parameters within the CES solely on the basis of the provisions of the European Union law. However, today this is not the case in the CES agreement.

Another issue is the creation of a customs union for the CES member-states. However, in the documents fixing its European choice, Ukraine sets itself the task of joining the customs union with the EU. And the agreement on the Common Economic Space also aims to create a customs union and does not spell out the answers to the question how to combine the two tasks. Instead, one can hear the argument that we will first achieve competitiveness through integration into the CES and then integrate into the European Union. It is necessary to develop a unified strategy for the European integration, in which both the processes of our accession to the European Union and the development of opportunities in the post-Soviet space are clearly coordinated - with the focus on the formation of a wide pan-European economic space (Sidenko, 2012).

Based on the scientific achievements of these and other researchers, we will try to find out the place of Ukraine in the international coordinate system and the most probable vector of development, which is derived from the sum of external and internal vectors that affect our country. The framework, in this case, is the process of globalization against which all processes unfold. If they coincide with the dominant directions of the global development of the society, then their strength is much greater, and if on the contrary - contradictory, it leads to their attenuation. 
In order to enter the EU, Ukraine must already have the prerequisites for itself to rise and be at the level of a European state. The country has the potential to become not just a European country, but a global state, and if it adopts and develops the global values, it can become even higher than Europe. Europe is now living rather than global values, but European values, and globalization is only an element of trade for it. As soon as Ukraine is able to overcome Europe's limitations on its own, Europe itself will be interested in Ukraine becoming a part of it (Molnar et al., 2018).

Let us note what prevents this. Firstly, the image of Ukraine in the world as a corrupt state. Secondly, the functioning of the Ukrainian economy does not comply with the international legal standards in terms of taxation system, regulatory system, transparency of the financial transactions, etc., which is the cause of unfavourable investment climate. Thirdly, despite the high level of declarations made about the need to attract foreign investment, there is in fact no sound effective public policy strategy to create a favourable investment climate. Ways to create such a climate: low tax rates, a stable political and legal system, identified priority areas for attracting investment, creating special zones and more. Fourthly, it is necessary to regulate the work of foreign transnational companies (hereinafter-TNCs). They have to create modern production in our country, and the Ukrainian state, for its part, has to create favourable conditions for them to want to invest in Ukraine, but in such a way that it does not harm their own business.

According to some experts, Ukraine is too open to the world, but somewhat one-sided. The structure of Ukrainian exports is dominated by products of chemistry and metallurgy, that is, almost raw materials (Molnar et al., 2018). With regard to political integration, we agree with experts who advise not to be attached to one particular center of political gravity, but to interact with all powerful states in the areas most relevant to the Ukrainian interests. Ukraine's increasing role in globalization will increase with its economy, internal consensus on key foreign policy and foreign economic orientations, strengthening of the political system and having its own strategic plan for country involvement in the globalization processes. Ukraine is very little involved in the globalization processes. This is due to the fact that Ukraine is a fairly closed country that is not integrated into international economic and very specifically integrated into international political relations. Of course, one cannot be free from globalization as the globalization progresses. Therefore, of course, the manifestations of globalization affect us as well. However, if we consider the positive and negative aspects of globalization, Ukraine mostly does not use the positives, while being affected by the negatives of globalization.

If we consider the most widespread negatives of globalization, we can speak of the dominance of some wealthier country in the economic and even cultural sphere. They also include the commercialization of the cultural values, the subordination of the world to the interests of powerful transnational corporations, and more. Globalization in its current form is subordinated to the interests of the world capital (transnational corporations) operating, using the military-political power of the leading Western powers, especially the USA. However, these states themselves, especially the USA, are leading the world globalization process in the pursuit of their own geopolitical interests, largely autonomous to those of leading transnational companies.

Modern Ukraine has a dual and slightly unfavourable position in terms of geopolitical self-identification. The point here is, first of all, in the contradiction between the economic and political interests of our establishment. In economic relations we have nothing to expect from the West. Western investment is insignificant and does not relate to the development of advanced technologies, and Western markets remain and will remain virtually closed to us. However, the Ukrainian authorities seek the wing and custody of the West. The latter defines its declarative statements (little confirmed by real actions) about aspirations for Euro-Atlantic structures. On the other hand, the real markets for Ukraine are the Caucasian and Central Asian states, as well as the countries of Asia and Africa, where our goods can be successfully sold (Sidenko, 2012).

However, Ukraine must integrate into international economic relations and find its real place and opportunities to maximize the benefits of globalization and minimize the negatives. Given the current state of the national economy, given the various ratings, it is difficult to say that Ukraine will soon become a leading country. Therefore, one must realistically consider its role and place in the world. It should be guided by European values and position itself as a European country. However, it is not fundamental whether Ukraine is a member of the EU or not. Examples can be given of Switzerland or Norway that are not EU member states, but are European states.

The integration into the CES can really lead to improvement of the quality of work of the Ukrainian enterprises, to increase of budget revenues, to improvement of financing of the social sphere, and well- 
being of the population. Therefore, if the EU is a strategy, a common course, then the CES is a tactical current case that would allow to a certain extent to revive the national economy, which would again raise the standard of living of the citizens.

Ukraine's economic interests (energy supply, export opportunities for its goods, etc.) orient Ukraine to the East and South - Central Asia, China, Iran, and others. However, because of fears of strengthening Russia's political dominance, the Ukrainian establishment and much of the society, especially in the Western regions, are seeking a full rapprochement with the West and joining the Euro-Atlantic structures. The West is really interested in minimizing Russian influence in Ukraine, but it is not going to open its markets for our goods, invest in our economy any significant funds and share with us the latest technologies. The contradictions between the economic and political interests of Ukraine determine the duality and inconsistency of its foreign policy.

Ukraine is not sufficiently involved in the globalization processes. However, the world development of globalization involves Ukraine and our political elite. As soon as our nationally conscious political elite start to save money in Ukraine, there is a prospect that Ukraine will have a special national factor to consider. However, if you look at the world processes, there are several features worth noting. Ukraine as a territorial space is interesting enough for the world political players. Ukraine is not interesting because it has some achievements. However, it has technological and other resources, it is interesting as a geostrategic space, as a transit territory. Ukraine is interesting as an experiment of traversing a large territory from one political and economic system to another. Our state is the optimal form where, avoiding civil conflict, one can create structures that either integrate into the world community (meaning the transatlantic community) or be integrated into the East (not necessarily negatively coloured by this concept) and accept the traditions of the East (Voitovych, 2012).

For objective reasons Ukraine cannot, in principle, play a prominent role in the world globalization process. This is due to its low position in the world economy, lack of national consensus on key issues of foreign economic and foreign policy orientation, weakness and contradiction of the political course, and many others. Ukraine could only increase its role in the world globalization process in the conditions of rapid economic development on an innovative basis, reaching public consensus on the most important issues of the internal and external strategy development and, thus, a decisive, independent foreign policy without constant review of the instructions (whatever they came out of).

As for the other aspect of globalization - integration, Ukraine's desire to integrate both into the EU and the CES raises some questions. The European Union not only prevents, but also seeks to stimulate the development of the regional economic cooperation among the countries with which it has partnerships. In particular, the concept of the European Commission "Greater Europe" that offers new opportunities for joining the European economic structures of neighbouring countries (including Ukraine) provides for the promotion of cooperation and development of free trade between these countries (Sokolenko, 2002). However, the problem is that it is impossible to combine the two integration processes if the principles of their construction are incompatible. In this respect, there are significant problems in the Common Economic Space agreement, signed in September 2003, in terms of its compliance with Ukraine's European integration course. Unfortunately, the agreement has no guarantees of basing this process on EU principles and there is no clear guarantee of using this mechanism as a mechanism for joint entry into the European economic space.

Therefore, it is possible to speak about the high probability that already in the first stages of implementation of the concept of development of integration within the Common Economic Space there will be a mismatch on certain economic parameters with the standards of the European Union. For example, there is a problem of widespread harmonization of Ukraine's economic mechanisms with the CES member-states. At the same time, we have similar commitments to the European Union. So in alignment with which economies do we focus? Perhaps we should make it clear that we will coordinate the economic parameters within the CES solely on the basis of the European Union law. However, today this is not the case in the CES agreement.

\section{Conclusions}

It is impossible to avoid the impact of the globalization processes. Ukraine is still poorly involved in these processes. The reasons for the low level of involvement of Ukraine in the world globalization processes are the unpreparedness and unwillingness of the political elite to participate in them, primarily due to the lack of a global outlook and lack of knowledge of foreign languages; lack of consensus in the 
society regarding the direction of development of the country; absence of powerful domestic transnational corporations. The way is seen in the rotation of the elites, the creation of their own TNCs, the conduct of their own independent policies, subject to widespread public support, adopting a national course on globalization. There is no consensus among experts as to the prospects of Ukraine's integration with the EU and the CES, but Ukraine must be as close as possible to all possible unions, associations, etc. which provide it with security and markets. To do this, one must strive to be the subject of integration initiatives under any circumstances. Ukraine needs to come up with a unified strategy for the globalization of the country in which the processes of our accession to the European Union and the Common Economic Space and to other existing associations, organizations and unions, and to the ones that will appear. The national interests of Ukraine are a measure of evaluation of any arrangements. Active entry into the global world requires adequate staffing, the creation of its own TNCs, the harmonization of all systems of the country to the international standards for its own flexible policies, on condition.

\section{References:}

1. Sokolenko, S.I. (2002). Proizvodstvennye sistemy globalizatsii: seti, al'yansy, partnerstva, klastery [Globalization production systems: networks, alliances, partnerships, clusters]. Kyiv: Logos, 648 p. [in Russian].

2. Pekhnyk, A.V., Prysiazhniuk, Yu.I. (2018). Transnatsionalni korporatsii u realiiakh suchasnoho mizhnarodnoho biznesu [Transnational corporations in the realities of modern international business]. Zbirnyk naukovykh prats Cherkaskoho derzhavnoho tekhnolohichnoho universytetu. Seriia "Ekonomichni nauky"Collection of scientific works of Cherkasy State Technological University. Series "Economic Sciences", iss. 51, pp. 82-90 [in Ukrainian].

3. Voitovych, R.V. (2012). Hlobalizatsiia yak universalna forma istorychnoi dynamiky perekhidnykh suspilstv [Globalization as a universal form of historical dynamics of transitional societies]. Visnyk Natsionalnoi akademii derzhavnoho upravlinnia pry Prezydentovi Ukrainy - Bulletin of the National Academy of Public Administration under the President of Ukraine, iss. 1, pp. 21-32 [in Ukrainian].

4. Sidenko, V.R. (2012). Modyfikatsiia svitovoi ekonomiky pid vplyvom novitnikh faktoriv hlobalnoi transformatsiinoi kryzy [Modification of the world economy under the influence of the latest factors of the global transformation crisis]. Ekonomika Ukrainy - Ukraine economy, no. 5, pp. 18 -31 [in Ukrainian].

5. Pavlenko, Yu.V. (2000). Hlobalizatsiia ta yii protyrichchia [Globalization and its contradictions]. Nauka ta naukoznavstvo - Science and science of science, no. 3, pp. 11-23 [in Ukrainian].

6. Molnar, O.S., Popovych, I.O., Tokar, M.M. (2018). Hlobalizatsiia - vazhlyvyi faktor suchasnykh mizhnarodnykh ekonomichnykh vidnosyn [Globalization is an important factor in modern international economic relations]. Formuvannia rynkovykh vidnosyn v Ukraini - Formation of market relations in Ukraine, no. 11, pp. 20-24 [in Ukrainian]. 


\title{
ГЛОБАЛІЗАЦИЙНИЙ ПРОЦЕС УКРАЇНСЬКОГО СУСПІЛЬСТВА ЯК УНІВЕРСАЛЬНА ФОРМА ІСТОРИЧНОЇ ДИНАМІКИ
}

\author{
Іван ШКУРАТ, \\ доиент кафедри політології \\ Університету Григорія Сковороди у Переяславі, \\ докторант Інституту підготовки кадрів Держсавної служби зайнятості України, \\ кандидат наук з державного управління \\ ishiva@ukr.net \\ https//orcid.org/0000-0002-8810-2890
}

Мета. У статті висвітлено питання, що полягає в аналізі впливу глобалізаиії на розвиток і становлення украӥнського суспільства.

Методи. У дослідженні використані такі загальнонаукові та спещіальні методи: наукове узагальнення й систематизачія - для визначення характеристик глобалізації; порівняльний аналіз - для зіставлення розвитку країн, що входять до Європейського Союзу, з іншими краӥнами, уряд яких прямує до інтеграиії з Європою; системний аналіз - для виявлення позитивних і негативних сторін впливу глобалізації на соціальноекономічний та політичний розвиток деяких країн світу; логічний синтез - для пояснення результатів дослідження.

Результати. Визначено, що позитивний вплив глобалізації полягає в значному й неухильному збільшенні світового промислового виробництва та торгівлі, зниженні темпів інфляції, широкому впровадженні нових принципів і методів господарської діяльності. Обтрунтовано, що Україна має потенціал для того, щоб стати не просто європейською, а навіть глобальною державою. Визначено, що глобалізація загалом і світогосподарських відносин зокрема - це об'єктивний процес, який виражає сукупність умов розвитку сучасного світового співтовариства та насамперед науково-технічного й економічного прогресу. Це неминучий етап сходження людства до нових обріїв, що в підсумку несе позитивні початки, проте водночас не позбавлений серйозних і масштабних протиріч, а отже, не виключає негативні впливи. Констатовано, що основним негативом від глобалізаиії є домінування «заможнімої» країни над менш розвиненою в економічній і навіть культурній сферах. До негативних рис також належать комериіалізаиія культурних иінностей, підпорядкування світу інтересам потужних транснаціональних корпоращій тощо. Глобалізачія в ії сучасному вигляді підпорядкована інтересам світового капіталу (трансначіональних корпорацій), які діють, використовуючи військово-політичну могутність провідних західних держав. Однак иі держави керують світовим глобалізаційним процесом в ім'я реалізації власних геополітичних інтересів. Висновки. Встановлено, що функиіонування економіки Украйни не відповідає міжнародним правовим нормам у частині, що стосується системи оподаткування, системи регулювання, прозорості фінансових трансакиій тощо, що й постає причиною несприятливого інвестииійного клімату. Незважаючи на те, щяо на високому рівні декларативно робляться заяви про необхідність залучення іноземних інвестищій, насправді відсутня зважена дієва стратегія державної політики щодо створення сприятливого інвестииійного клімату.

Ключові слова: глобалізація, політика, євроінтеграція, національна економіка, уряд. 